\title{
Genetic Analysis of cagA and vacA Genes in Helicobacter Pylori Isolates and Their Relationship with Gastroduodenal Diseases in the West of Iran
}

\author{
Negar Souod ${ }^{1, *}$, Mohammad $\operatorname{Kargar}^{2}$, Abbas Doosti $^{3}$, Reza Ranjbar $^{4}$, Meysam Sarshar $^{4}$ \\ ${ }^{1}$ Young Researchers and Elite Club, Jahrom Branch, Islamic Azad University, Jahrom, IR Iran \\ 2 Department of Microbiology, Jahrom Branch, Islamic Azad University, Jahrom, IR Iran \\ ${ }^{3}$ Department of Biotechnology, Shahrekord Branch, Islamic Azad University, Shahrekord, IR Iran \\ ${ }^{4}$ Molecular Biology Research Center, Baqiyatallah University of Medical Sciences, Tehran, IR Iran \\ ${ }^{*}$ Corresponding author: Negar Souod, Young Researchers and Elite Club, Jahrom Branch,Islamic Azad University, Jahrom, IR Iran Tel: +98-3813361045, Fax: \\ +98-3813361064, E-mail: negarsouod@yahoo.com.
}

\begin{abstract}
A B S T R A C T
Background: Helicobacter pylori have different virulence factors which are associated with several gastroduodenal diseases; however, this association is variable in different geographical regions. Data of genotypes of Iranian H. pylori isolates are few.

Objectives: The aim of the current study was to investigate the cagA/vacA genotypes of Helicobacter pylori isolates and determine the relationship between these genotypes with respect to different gastric disorders in patients of Chaharmahalo Bakhtiarian.

Materials and Methods: In this cross-sectional study, gastric biopsies were taken from 200 patients with gastrodoudenal diseases. Histopathological features were recognized by specialist. The samples were subjected to PCR for detection and identification of ureC, cagA and vacA genes.

Results: The frequency of the vacA genotypes, sa1/m1, s1a/m1b, s1a/m2, s1b/m1a, s1b/m1b, s1b/m2, s1c/m1a, s1c/m1b, s1c/m2, s2/m1a, s2/m1b and s2/ $\mathrm{m} 2$ were 27(6.6\%), 8(4.3\%), 45(28.04\%), 7(3.7\%), 5(2.5\%), 10 (6.1\%), 12 (7.4\%), $4(2.5 \%), 18(11 \%), 6(3.7 \%), 0$ and 22(13.5\%) respectively. The cagA gene was detected in $92 \%$ of strains. Based on our findings, it seemed that cagPAI and vacA s1 genotypes were associated with some gastric disorders in patients with $\mathrm{H}$. pylori. In this region, the isolates carrying sia/m2 were the most prevalent.

Conclusions: We found considerable relationship between s1a/m1a, s1a/m2, s2/m2 and s1c/m1a and some gastric disorders. Further studies about the role of $\mathrm{H}$. pylori virulence factors and gastric disorders were recommended.
\end{abstract}

Keywords: Helicobacter Pylori; VacA Protein, Helicobacter Pylori; CagA protein, Helicobacter Pylori

\section{Background}

Helicobacter pylori is major causes of chronic gastritis. They are also involved in the pathogenesis of several diseases including gastric and duodenal ulcers, gastric adenocarcinoma and mucosa-associated lymphoid tissue lymphoma (1). Several H. pylori virulent genes have been identified to contribute to the severity of these diseases.

Copyright ( $)$ 2013, Iranian Red Crescent Medical Journal; Published by Kowsar Corp.

Article type: Research Article; Received: 10 Dec 2011; Revised: 09 Jan 2013; Accepted: 20 Jan 2013; Epub: 05 May 2013; Ppub: 05 May 2013

Implication for health policy/practice/research/medical education:

There are geographic variations in H. pylori strains and different strains may cause distinct gastric diseases in different areas. Unfortunately, existing data is contradictory and cannot explain the pathogenic role of this bacterium in the development of different gastric diseases. Furthermore, it might be useful to know the genetic diversity of H. pylori strains in Chaharmahalo Bakhtiari, one of the risky provinces of Iran with regard to eradicate dangerous strains.

DPlease cite this paper as:

Souod N, Kargar M, Doosti A, Ranjbar R, Sarshar M. Genetic Analysis of cagA and vacA Genes in Helicobacter Pylori Isolates and Their Relationship with Gastroduodenal Diseases in the West of Iran. Iran Red Cres Med J. 2013; 15(5): 371-5. DOI: 10.5812/ircmj.3732 
morphic, comprising variable signal regions (type s1 or $\mathrm{s} 2$ ) and mid-regions (type $\mathrm{m} 1$ or $\mathrm{m} 2$ ). The type s1/m1 vacA strains causes more epithelial cell damage than type s1/ $\mathrm{m} 2$, whereas type $\mathrm{s} 2 / \mathrm{m} 2$ and the rare $\mathrm{s} 2 / \mathrm{m} 1$ are non-toxic due to the presence of a short 12-residue hydrophilic extension on the $s 2$ form $(3,6)$. The s-region is classified into $\mathrm{s} 1$ and $\mathrm{s} 2$ types and the m-region into $\mathrm{m} 1$ and $\mathrm{m} 2$ types. The s1 type is further classified into s1a, s1b and s1c subtypes, and the $\mathrm{m} 1$ into m1a and m1b subtypes. The mosaic combination of $s$ and m-region allelic types determines the particular cytotoxic and, consequently, the pathogenicity of the bacterium $(7,8)$. There is a geographical variation in the vacA genotypes $(9,10)$. For example, studies have consistently shown that vacA s1a strains predominate in northern Europe, s1b in Central and South America, Spain and Portugal, s1a and s1b in the USA and s1c in East Asia (10). These differentiations may cause variations in the prevalence of gastric diseases in these areas. Thus, existing data are contradictory and cannot explain the pathogenic role of H.pylori in the development of different gastric diseases. Furthermore, it might be useful to know the genetic diversity of H.pylori strains in Chaharmahalo Bakhtiari, one of the risky provinces of Iran.

\section{Objectives}

The aim of the current study was to investigate the cagA/vacA genotypes of Helicobacter pylori isolates and determine the association between these genotypes with different gastric disorders in Chaharmahalo Bakhtiarian patients.

\section{Materials and Methods}

\subsection{Collection of Patient Samples}

From June to November 2009, 200 consecutive patients with dyspeptic symptoms attending the endoscopy suite of gastroenterology section of Hospital of Shahrekord University of Medical Sciences (SUMS) enrolled in the study. The questionnaires, including medical history and demographic data, were recorded for each patient. All studied patients signed an informed consent form before endoscopy and declared their willingness to allow the application of their anonymous data for research purposes. For each patient, two biopsy specimens were taken from the antrum using a disinfected endoscope. One piece of each specimen was examined by Rapid Urease Test (RUT) for detection of H. pylori. RUT was performed with a Gastro urease kit (Baharafshan, Iran). The second piece from positive samples in RUT was placed in $0.1 \mathrm{ml}$ of sterile saline solution and was sent to Biotechnology Research Center of Islamic Azad University, Shahrekord Branch for further studies.

\subsection{Genomic DNA Extraction and Polymerase Chain Reaction}

DNA was isolated from biopsy specimens using Genomic DNA purification kit (DNPTM, CinnaGen, Iran) according to the recommendations of manufacture Primers sequences used for the PCR include as follows: ET-2U (5'-CCCTCACGCCATCAGTCCCAAAAA-3') and ET-2L (5'-AAGAAGTCAAAAACGCCCCAAAAC-3') ( 4 ). Primers used for PCR assays of vacA and cagA genes are listed in (Table 1) $(11,12)$.

Table 1. Primers Used for PCR Analysis of vacA and cagA Genes (, )

\begin{tabular}{|c|c|c|c|}
\hline Region & Primer & Sequence ( $\left.5^{\prime}-3^{\prime}\right)$ & $\begin{array}{l}\text { Size and location of PCR } \\
\text { Product }\end{array}$ \\
\hline $\operatorname{ureC}(\operatorname{glm} M)$ & GlmM1-R GlmM1-F & $\begin{array}{l}\text { GCTTACTTTCTAACACTAACGCGC GGATAAGCTTTTAGGGGT- } \\
\text { GTTAGGGG }\end{array}$ & 296bp \\
\hline s1a & vacA s1a-F VA1-R & CTC TCG CTT TAG TAG GAG C CTG CTT GAA TGC GCC AAA C & 213 bp (843-1055) \\
\hline s1b & SS3-F VA1-R & AGC GCC ATA CCG CAA GAG CTG CTT GAA TGC GCC AAA C & $187 \mathrm{bp}(869-1055)$ \\
\hline s1c & vacA s1c-F VA1-R & CTC TCG CTT TAG TGG GGY T CTG CTT GAA TGC GCC AAA C & 213 bp (843-1055) \\
\hline s2 & SS2-F VA1-R & $\begin{array}{l}\text { GCT AAC ACG CCA AAT GAT CC CTG CTT GAA TGC GCC AAA } \\
\text { C }\end{array}$ & 199 bp (433-631) \\
\hline m1a & VA3-F VA3-R & $\begin{array}{l}\text { GGT CAA AAT GCG GTC ATG G CCA TTG GTA CCT GTA GAA } \\
\text { AC }\end{array}$ & 290 bp (2741-3030) \\
\hline $\mathbf{m 1 b}$ & VAm-F3 VAm-R3 & $\begin{array}{l}\text { GGC CCC AAT GCA GTC ATG GA GCT GTT AGT GCC TAA AGA } \\
\text { AGC AT }\end{array}$ & $291 \mathrm{bp}(2741-3031)$ \\
\hline $\mathbf{m 2}$ & VA4-F VA4-R & GGA GCC CCA GGA AAC ATT G CAT AAC TAG CGC CTT GCA & 352 bp (976-1327) \\
\hline cagA & cagA-U cagA-L & $\begin{array}{l}\text { GGA ATA CCA AAA ACG CAA AAA CCA CCC CAC AAT ACA } \\
\text { CCA GCA AAA CT }\end{array}$ & 30obp \\
\hline
\end{tabular}

DNA samples from H. pylori (D0008, Genekam, Germany) were used as a positive control of cagA and vacA genes, and sterile distilled water was used as a negative control. PCR was done in $20 \mu \mathrm{L}$ (for H. pylori) or $25 \mu \mathrm{L}$ (for vacA and cagA) of total reaction volume containing 1.5 mM MgCl2 (2.0 mM for cagA), 50 mM KCl, 10 mM Tris- $\mathrm{HCl}$ 
(pH 9.0), 0.1\% Triton X-100, $200 \mu \mathrm{M}$ dNTPs each (Fermentas), $0.4 \mu \mathrm{M}$ primers, $0.3 \mathrm{U}$ of Taq DNA polymerase (Fermentas), and $2 \mu \mathrm{L}(40-260 \mathrm{ng} / \mu \mathrm{L})$ of DNA. PCR was performed in a DNA Thermal Cycler (Eppendrof Mastercycler 5330, Eppendorf-Nethel-Hinz GmbH, Hamburg, Germany), with 40 cycles for ET2 primer and 35 cycles for vacA and cagA primers. Each cycle consisted of denaturation at $95^{\circ} \mathrm{C} / 45$ seconds; annealing at $59^{\circ} \mathrm{C} / 30$ seconds for ET2, $52^{\circ} \mathrm{C} / 45$ seconds for vacA, and $58^{\circ} \mathrm{C} / 45$ seconds for cagA; and extension at $72^{\circ} \mathrm{C} / 45$ seconds (11). There was another time extension ( 6 minute) at $72^{\circ} \mathrm{C}$. PCR products were visualized by electrophoresis in $1 \%$ agarose gel, stained with ethidium bromide, and examined under ultraviolet illumination.

\subsection{Statistical Analysis}

The data were analyzed by SPSS software (Version 17.spss Inc, USA) and P value was calculated using Chi-square and Fisher's exact tests to find the significant relationship. $\mathrm{P}$ value less than 0.05 was statistically significant.

\section{Results}

Out of 200 gastric biopsy specimens, 164 (82\%) were confirmed to be $\mathrm{H}$. pylori infection positive by RUT. Of all patients studied, 79 (48.1\%) were male and 85 (51.8\%) were female, with a mean age of $47 \pm 17$ years (Range 15 to 88 years old). Sixteen patients (11.8\%) had Gastric ulcers, 22 (16.2\%) had Duodenal ulcers, 160 (97.5\%) had Gastritis, 3 (2.2\%) had Gastric cancer and 3 (2.2\%) had Duodenit. Possible combinations of vacA $s$ and $m$ regions were determined in Iranian population. Overall 63 samples were classified as vacA s1/m1, 73 samples as s1/m2, 22 as s2/m2 and 6 as s2/ $\mathrm{m} 1$ genotypes. Out of $135 \mathrm{~s} 1$ strains, all the samples were successfully sub-typed using s1a, s1b and s1c specific primers. Among them, 79 (48.1\%) were s1a positive, $21(12.8 \%)$ were s1b positive and $35(21.3 \%)$ were s1c positive. In the case of $\mathrm{m} 1$ sub-typing, the distribution of m1a and $\mathrm{m} 1 \mathrm{~b}$ was $31.7 \%$ and $9.14 \%$ respectively. M2 was found in $58.5 \%$ of the cases (Table 2).

\begin{tabular}{|c|c|c|c|c|c|c|}
\hline vacA genotypes & $\begin{array}{l}\text { G. } \mathbf{U}^{\mathrm{a}}(\mathbf{n}=16) \text {, } \\
\text { No. }(\%)\end{array}$ & $\begin{array}{l}\text { D. } \mathbf{U}^{\mathrm{a}}(\mathbf{n}=\mathbf{2 2}) \text {, } \\
\text { No. }(\%)\end{array}$ & $\begin{array}{l}\text { G.C } C^{\mathrm{a}}(\mathbf{n}=3), \\
\text { No. }(\%)\end{array}$ & $\begin{array}{l}\text { C. } G^{\mathrm{a}}(\mathbf{n}=160), \\
\text { No. }(\%)\end{array}$ & $\begin{array}{l}\text { DUO }^{\mathrm{a}}(\mathbf{n}=3) \\
\text { No. }(\%)\end{array}$ & $\begin{array}{l}\text { Total }(n=164) \text {, } \\
\text { No. }(\%)\end{array}$ \\
\hline S1a & $9(56.2)$ & $11(50)$ & $1(33.3)$ & $76(47.5)$ & $1(33.3)$ & $79(48.1)$ \\
\hline S1b & $3(18.7$ & $1(4.5)$ & $1(33.3)$ & $20(12.5)$ & $1(33.3)$ & $21(12.8)$ \\
\hline S1c & $3(18.7)$ & $3(13.6)$ & 0 & $34(21.2)$ & 0 & $35(21.3)$ \\
\hline S2 & $1(6.2)$ & $7(31.8)$ & $1(33.3)$ & $28(17.5)$ & $1(33.3)$ & $29(17.6)$ \\
\hline M1a & $4(25)$ & $9(40.9)$ & $2(66.6)$ & $52(32.5)$ & 0 & $52(31.7)$ \\
\hline M1b & $3(18.7)$ & $3(13.6)$ & 0 & $15(9.3)$ & 0 & $15(9.1)$ \\
\hline M2 & $9(56.2)$ & $10(45.4)$ & $1(33.3)$ & $92(57.5)$ & $3(100)$ & $97(59.1)$ \\
\hline S1a/m1a & $1(6.2)$ & $4(18.1)$ & $1(33.3)$ & $27(16.8)$ & 0 & $27(16.4)$ \\
\hline S1a/m1b & $2(12.5)$ & $2(9.09)$ & 0 & $7(4.3)$ & 0 & $8(4.8)$ \\
\hline S1a/m2 & $6(37.5)$ & $2(9.09)$ & 0 & $41(25.6)$ & $1(33.3)$ & $45(27.4)$ \\
\hline S1b/m1a & $2(12.5)$ & 0 & 0 & $6(3.7)$ & 0 & $7(4.2)$ \\
\hline $\mathbf{S 1 b} / \mathbf{m} 1 \mathbf{b}$ & 0 & 0 & 0 & $4(2.5)$ & 0 & $5(3.04)$ \\
\hline $\mathbf{S 1 b} / \mathbf{m} 2$ & $1(6.2)$ & $1(4.5)$ & $1(33.3)$ & $10(6.2)$ & $1(33.3)$ & $10(6.09)$ \\
\hline S1c/m1a & $1(6.2)$ & $1(4.5)$ & 0 & $12(7.5)$ & 0 & $12(7.3)$ \\
\hline S1c/m1b & $1(6.2)$ & $1(4.5)$ & 0 & $4(2.5)$ & 0 & $4(2.4)$ \\
\hline S1c/m2 & $1(6.2)$ & $1(4.5)$ & 0 & $18(11.2)$ & 0 & $18(10.9)$ \\
\hline S2/m1a & 0 & $1(4.5)$ & $1(33.3)$ & $6(3.7)$ & 0 & $6(3.6)$ \\
\hline $\mathrm{S} 2 / \mathrm{m1b}$ & 0 & 0 & 0 & 0 & 0 & 0 \\
\hline S2/m2 & $1(6.2)$ & $6(27.2)$ & 0 & $22(13.7)$ & $1(33.3)$ & $22(13.4)$ \\
\hline
\end{tabular}

a Abbreviation: C.G, Chronic gastritis; D.U, Duodenal ulcer; DUO, Duodenit; G.C, Gastric cancer; G.U, Gastric ulcer

One hundred fifty one (92\%) out of 164 ureC- positive samples carried cagA gene. One hundred twenty eight (78.04\%) strains with vacA s1 genotype were cagA positive while 23 (14.02\%) strains with vacA s2 genotype were cagA positive, indicating that the presence of cagA gene was significantly associated with the vacA s1 genotype ( $\mathrm{P}=$ $0.004)$. In particular, most samples (95.5\%) with the vacA $\mathrm{s} 1 / \mathrm{m} 2$ genotypes were cagA positive. Also, the prevalence of cagA gene was not related to the clinical outcomes (Table 3). 


\begin{tabular}{|c|c|c|c|}
\hline Patients groups & H. pylori-positive (n=164), No. (\%) & cagA-negative ( $n=13)$, No. (\%) & cagA-positive $(n=151)$, No. $(\%)$ \\
\hline G.U $\mathbf{U}^{\mathrm{a}}$ & $16(9.7)$ & $2(15.3)$ & $14(9.2)$ \\
\hline D. $U^{\mathrm{a}}$ & $22(13.4)$ & $2(15.3)$ & $20(13.2)$ \\
\hline G.C $C^{a}$ & $3(1.8)$ & $1(7.6)$ & $2(1.3)$ \\
\hline C.G ${ }^{a}$ & $160(97.5)$ & $147(94.2)$ & $12(7.5)$ \\
\hline DUO $^{\mathrm{a}}$ & $3(1.8)$ & 0 & $3(1.9)$ \\
\hline
\end{tabular}

a Abbreviation: C.G, Chronic gastritis; D.U, Duodenal ulcer; DUO, Duodenit; G.C, Gastric cancer; G.U, Gastric ulcer

\section{Discussion}

H. pylori are one of the most genetically diverse bacterial species which may be involved in the complex variety of gastro duodenal diseases in infected patients all over the world (13-16). The geographic prevalence of distinct H. pylori genotypes remains largely unknown (15). For instance, in Japan, South America, Turkey and Pakistan, the prevalence is more than $80 \%$, while in Scandinavia and England, the prevalence is between $20 \%$ and $40 \%$ (3). The prevalence of this bacterium in Iran is $60-90 \%$, indicating that Iran is a highly risky region for $\mathrm{H}$. pylori infection. The prevalence of this bacterium was $82 \%$ in our study indicating that our findings are consistent with previous reports in Iran (16-18). The vacA genotypes show considerable variability in different geographic regions (3). According to our results, $80 \%$ of samples had vacA s1a, b, c, also $\mathrm{m} 2$ genotypes and s1a/m2 was predominant in $\mathrm{H}$. pylori isolates. This finding is somewhat similar to Europe and North America, where vacA s1a, s1b and $\mathrm{m} 2$ are predominating too. Our isolates were similar to those isolated from East Asian isolates where s1c is predominant (15). This study showed that Iranian H. pylori isolates are very diverse in genotype and contain the East and the West elements. H. pylori strains concluding cagA gene are more virulent than cagA-negative strains (3). The prevalence of cagA-positive $\mathrm{H}$. pylori varied from one geographic region to another, e.g., 97\% in Korea, 94\% in Malaysia, 90\% in China, 78\% in Turkey and 53\% in Kuwait (19). In this study, we found cagA gene in $92 \%$ of the $\mathrm{H}$. pylori-positive population. This finding did not demonstrate the role of cagA as predictive marker for increased virulence feature of $\mathrm{H}$. pylori, because of the high positivity of this gene in all $\mathrm{H}$. pylori isolates. A strong association between the cagA and vacA status and peptic ulcer disease has been reported (20-22). Beil et al. suggested that the increased inhibitory effect of cagA-positive, cytotoxin-producing strains on mucin synthesis could be considered as a possible mechanism which is responsible for the increased risk of developing peptic ulceration with these $\mathrm{H}$. pylori strains (9). Gzyl et al. found that cagA gene correlated with active gastritis in infected children and adults. They also found that the majority of H. pylori strains carrying $\mathrm{s} 1 / \mathrm{m} 2$ vacA alleles were responsible for the higher levels of cytotoxin production (10). Our data were in agreement with those of Gzyl et al. and Beil et al., which suggest that $\mathrm{H}$. pylori strains with cagA and vacA s1 genotypes are associated with more severe gastritis $(9,10)$. Investigator's opinions about the association between vacA genotypes and gastric disorders were different. For example, in Iran, Jafari et al. found no correlation between them, (3) whereas Mohammadi et al. and Molaei et al. found that s1a allele were associated with more severe inflammation $(15,23)$. As results showed, we found an association between some diseases and some vacA genotypes but we couldn't introduce any allele as a marker of a disease. For instance, s2 m2 strains that are non-toxigenic in most regions of the world and are associated with NUD diseases were surprisingly more prevalent in PUD than in NUD patients and had direct association with duodenal ulcer in our evaluation. In Thailand, Japan, Korea, Colombia and America, no association had been found (21) whereas in Cuba, Lebanon, Hung Kung, China and most of the European countries, a significant association between $\mathrm{s} 1$ allele and PUD diseases had been reported (20, 21, 24, 25). Data analysis revealed a significant association between Duodenal ulcer and s1a/m1a $(\mathrm{P}=0.04), \mathrm{s1a} / \mathrm{m} 2(\mathrm{P}=0.02)$ and surprisingly s2m2 $(\mathrm{P}=0.05)$ genotypes. We observed an association between Gastritis diseases and s1c/m2 (P = 0.01). We didn't find any relationship between other diseases with regard to vacA genotypes. In conclusion, we found that the cagA-positive $\mathrm{s} 1 / \mathrm{m} 2 \mathrm{H}$. pylori were dominant genotypes in the patients under study. The cagA gene positivity rate was probably not closely associated with severity of the disease. H. pylori strains including vacA s1 genotype were associated with more severe gastritis.

\section{Acknowledgements}

The authors would like to thank Mr. Momeni and Mr. Ramezani at the Biotechnology Research Center of the Islamic Azad University of Shahrekord and Endoscopy Unit of Hajar Hospital of Shahrekord, for their sincere technical and clinical support.

\section{Authors' Contribution}

Souod $\mathrm{N}$ and Kargar M defined the research theme; Doosti A and Kargar M designed methods and experiments; Doosti A, Souod N and Sarshar M carried out the 
laboratory experiments; Ranjbar R and Souod $\mathrm{N}$ analyzed the data, interpreted the results and wrote the paper.

\section{Financial Disclosure}

All authors declare that there is no financial disclosure.

\section{Funding Support}

The study was supported by Young researcher's club financially.

\section{References}

1. Tanvir A, Khawar S, Muhammd R, Mukhtar M, Bilal R, Khanum A Prevalence of Helicobacter pylori pathogenicity-associated cagA and vacA genotypes among Pakistani dyspeptic patients. FEMS Immunol Med Microbiol. 2009;55(1):34-8.

2. Iamaroon $A$, Chaimano S, Linpisarn S, Pongsiriwet $S$, Phornphutkul K. Detection of Helicobacter pylori in recurrent aphthous ulceration by nested PCR. J Oral Sci. 2003;45(2):107-10.

3. Jafari F, Shokrzadeh L, Dabiri H, Baghaei K, Yamaoka Y, Zojaji H, et al. vacA genotypes of Helicobacter pylori in relation to cagA status and clinical outcomes in Iranian populations. Jpn J Infect Dis. 2008;61(4):290-3.

4. Li C, Ha T, Ferguson DA, Jr, Chi DS, Zhao R, Patel NR, et al. A newly developed PCR assay of $\mathrm{H}$. pylori in gastric biopsy, saliva, and feces. Evidence of high prevalence of $\mathrm{H}$. pylori in saliva supports oral transmission. Dig Dis Sci.1996;41(11):2142-9.

5. Peach HG, Pearce DC, Farish SJ. Helicobacter pylori infection in an Australian regional city: prevalence and risk factors. Med J Aust. 1997;167(6):310-3.

6. Argent RH, Thomas RJ, Letley DP, Rittig MG, Hardie KR, Atherton JC. Functional association between the Helicobacter pylori virulence factors VacA and CagA. J Med Microbiol. 2008;57(Pt 2):145-50.

7. Momtaz H, Souod N, Dabiri H. Comparison of the virulence factors of Helicobacter pylori isolated in stomach and saliva in Iran. Am J Med Sci. 2010;340(5):345-9.

8. Nahaei M, Sharifi Y, Taghi Akhi M, Ashghaezade M, Nahayei M, Fatahi E. Helicobacter pylori cagA and vacA genotypes and their relationship to peptic ulcer disease and non ulcer dysplasia. Res JMicrobiol. 2008;3(5):386-94.

9. Beil W, Enss ML, Muller S, Obst B, Sewing KF, Wagner S. Role of vacA and cagA in Helicobacter pylori inhibition of mucin synthesis in gastric mucous cells. J Clin Microbiol.2000;38(6):2215-8.

10. Gzyl A, Berg DE, Dzierzanowska D. Epidemiology of cagA/vacA genes in H. pylori isolated from children and adults in Poland.J Physiol Pharmacol.1997;48(3):333-43.

11. Wang J, Chi DS, Laffan JJ, Li C, Ferguson DA, Jr, Litchfield P, et al Comparison of cytotoxin genotypes of Helicobacter pylori in stomach and saliva. Dig Dis Sci. 2002;47(8):1850-6.

12. Yamazaki S, Yamakawa A, Okuda T, Ohtani M, Suto H, Ito Y, et al Distinct diversity of vacA, cagA, and cagE genes of Helicobacter pylori associated with peptic ulcer in Japan. $J$ Clin Microbiol. 2005;43(8):3906-16.

13. Farshad S, Alborzi A, Japoni A, Ranjbar R, Hosseini Asl K, Badiee P, et al. Antimicrobial susceptibility of Helicobacter pylori strains isolated from patients in Shiraz, Southern Iran. World J Gastroenterol. 2010;16(45):5746-51.

14. Izadi M, Fazel M, Sharubandi SH, Saadat SH, Farahani MM, Nasseri $\mathrm{MH}$, et al. Helicobacter species in the atherosclerotic plaques of patients with coronary artery disease. Cardiovasc Pathol. 2012;21(4):307-11.

15. Molaei M, Foroughi F, Mashayekhi R, Haghazali M, Zojaji H, Jafari F, et al. CagA status and VacA subtypes of Helicobacter pylori in relation to histopathologic findings in Iranian population. Indian J Pathol Microbiol. 2010;53(1):24-7.

16. Momtaz H, Souod N, Dabiri H, Sarshar M. Study of Helicobacter pylori genotype status in saliva, dental plaques, stool and gastric biopsy samples. World J Gastroenterol. 2012;18(17):2105-11.

17. Ghasemi A, Shirazi MH, Ranjbar R, Khorramizadeh MR, Daryani $\mathrm{NE}$, Hosseini M. The prevalence of cagA and cagE genes in Helicobacter pylori strains isolated from different patient groups by polymerase chain reaction. PakJ Biol Sci. 2008;11(22):2579-83.

18. Hosseinzadeh M, Khosravi A, Saki K, Ranjbar R. Evaluation of Helicobacter pylori infection in patients with common migraine headache. Arch Med Sci. 2011;7(5):844-9.

19. Nahaei M, Sharifi Y, Taghi Akhi M, Ashghaezade M, Nahayei M Fatahi E. Helicobacter pylori cagA and vacA genotypes and their relationship to peptic ulcer disease and non ulcer dysplasia. Res J Microbiol. 2008;3(5):386-94.

20. Torres L, Melián K, Moreno A, Alonso J, Sabatier C, Hernandez M, et al. Prevalence of vacA, cagA and babA2 genes in Cuban Helicobacter pylori isolates. World J Gastroentrol. 2009;15(2):204-10.

21. Wong B, Yin Y, Berg DE, Xia HH, Zhang JZ, Wang WH, et al. Distribution of Distinct vacA, cagA and iceA Alleles in Helicobacter pylori in Hong Kong. Helicobacter. 2001;6(4):317-24.

22. Yamaoka Y, Kodama T, Gutierrez O, Kim JG, Kashima K, Graham DY. Relationship between Helicobacter pylori iceA, cagA, and vacA status and clinical outcome: studies in four different countries. J Clin Microbiol.1999;37(7):2274-9.

23. Mohammadi M, Oghalaie A, Mohajerani N, Massarrat S, Nasiri M Bennedsen M, et al. Prevalence of Helicobacter pylori vacuolating cytotoxin and its allelic mosaicism as a predictive marker for Iranian dyspeptic patients. Bull Soc Pathol Exot. 2003;96(1):3-5.

24. Khayat A, Soweid A, Kattar M, Tahwil A, El Hajj A, Azar C, et al. Prevalence and clinical relevance of Helicobacter pylori cagA and vacA genes in Lebanese patients with gastritis and peptic ulcer disease. J Infect Develop Count. 2007;1(1):55-61.

25. Wang J, van Doorn LJ, Robinson PA, Ji X, Wang D, Wang Y, et al Regional variation among vacA alleles of Helicobacter pylori in China. J Clin Microbiol. 2003;41(5):1942-5. 